Vol. 8(3), pp. 029-041, July, 2018

ISSN: 2276-7762; ICV: 5.99

Copyright (C2018, the copyright of this article is retained by the author(s)

DOI Link: http://doi.org/10.15580/GJBS.2018.3.062718069

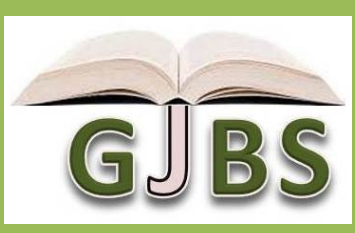

http://gjournals.org/ GJBS

\title{
Food Web Structure in Tropical Highland Stream Ecosystem
}

\section{UMAR D.M. ${ }^{* 1}$, HARDING J.S. ${ }^{2} \&$ CHAPMAN H.M. ${ }^{2}$}

\author{
${ }^{1}$ Gombe State University, Gombe, Nigeria. \\ ${ }^{2}$ School of Biological Sciences, University of Canterbury, Private Bag 4800, Christchurch \\ 8140, New Zealand.
}

\section{ARTICLE INFO}

Article No.: 062718069

Type: Research

DOI: 10.15580/GJBS.2018.3.062718069

Submitted: $27 / 06 / 2018$

Accepted: 07/07/2018

Published: 29/07/2018

${ }^{*}$ Corresponding Author

UMAR D.M

E-mail: danladiumar97 @gmail.com Phone: +2348065868471

\section{Keywords:}

Tropical highland streams, gut contents, stable isotope signature, food chain length, benthic community, Mambilla Plateau, Nigeria
The structure and properties of tropical stream food webs were investigated in nine second and third order streams, three in continuous sub-montane forest, three in tea plantations and three in maize fields. All were located on the Mambilla Plateau, north-east Nigeria. Components of all trophic levels (e.g., fine particulate organic matter [FPOM], coarse particulate organic matter [CPOM], algae, benthic invertebrates and fish) were sampled, and analysed by examination of gut contents and using stable isotopes techniques. Gut contents of key invertebrate species were categorised into eight types of food items: filamentous algae, diatoms, fungi, CPOM $\geq 1 \mathrm{~mm}$ (usually leaf litter and wood fragments), FPOM $1 \mathrm{~mm}$ (often amorphous detritus) and animal parts. Several food web properties were calculated and a basic food web was constructed using density data. Invertebrate species richness and density were higher in forest than in tea plantations and maize fields. Community and dietary analyses revealed that streams in the tea plantation and maize fields had simpler food webs incorporating fewer species and shorter food chains than those in continuous forest. However, potamonautid crabs (macroconsumers) and fish were present in all streams. Significant differences occured in three food web parameters calculated for streams in catchments differing in land uses: web size (ANOVA $F_{2,6}=15.509, P=0.004$ ), predator prey ratio (ANOVA $F_{2,6}=17.337, P=0.003$ ), standing biomass of invertebrates (AFDM); CPOM mass (ANOVA $F_{2,6}=8.727, P=0.016$ ) and algal (ANOVA $F_{2,6}=$ $37.599, P=0.001)$. Stable isotope analysis revealed that primary consumers assimilated a mixture of autochthonous and allochthonous carbon resources (CPOM and algae) in all streams. 


\section{INTRODUCTION}

Food webs are being increasingly used by ecologists to demonstrate patterns of biodiversity and energy flow in ecosystems (Thompson et al., 2012). A significant advantage of such an approach is that food webs can generate information on community structure, competition, nutrient dynamics, and cascading effects of predation which can be difficult to detect using other methods (Winemiller and Polis, 1996). Furthermore, food web studies have been used to measure the effects of disturbance on aquatic systems, for example McHugh et al., (2010) showed that disturbance can have an important role in restructuring food-webs in streams.

In forest stream ecosystems, food webs are typically driven by allochthonous organic inputs, (often dominated by leaf litter), as their primary energy source (Kaushik and Hynes, 1971; Vannote et al., 1980). Leaf litter is leached, colonized and decomposed by micro-organisms, and consumed by macroinvertebrate shredders (Dudgeon, 1982; Benfield, 1996; Gessner et al., 1999). As a result leaves and wood are broken down into fine particulate organic matter (FPOM). FPOM also enter directly from the riparian zone and can be consumed by invertebrate collectors. Invertebrate shredders, grazers and collectors are the major primary consumers in forest streams, and serve as a link between basal carbon resources and the predatory invertebrates and vertebrates. The biomass of benthic algae in shaded forest streams is typically low, but may be sufficient to support populations of grazing (scraping) invertebrates (March and Pringle, 2003; Brito et al., 2006). According to Brett et al. (2017) "in a period of unprecedented global change, land-use alteration and species invasions, we should be asking, which basal resources are the most important to sustain the growth and reproduction of aquatic invertebrates and fish in aquatic ecosystems".

Food web studies have now been conducted in aquatic habitats in many regions including streams in New Zealand (Townsend et al., 1998, Hogsden \& Harding, 2012), alpine lakes in North America (Weidman et al., 2011), Brazilian reservoirs (Okun et al., 2008) and streams in Japan (Kawaguchi and Nakano, 2001). However, the majority of these studies have been concentrated in temperate, European and North American streams and few have been undertaken in the tropics (Dudgeon, 2008). Thomson et al., (2012) stated that if we are to make reliable generalizations about global drivers of change, we need to improve our understanding beyond the current reliance on data from species-poor temperate systems. Thus, while commonly used model food web systems have served us well in terms of forming new theory, more diverse and potentially more complex systems such as those in the tropics, might behave differently (Thompson et al., 2012). However, studies of tropical aquatic food webs have so far demonstrated similarities in major environmental drivers to temperate streams, despite differences in the taxonomic composition of the fauna (see for example Yule, 1996; Winemiller and Jepsen, 1998; Lau et al., 2009).

Typically food-web studies have been undertaken on small spatial scales, yet the importance of cross-ecosystem movements of materials that support local stream food-webs has been clearly demonstrated (Polis et al., 1997). Numerous studies have confirmed the importance of detrital inputs in shaping forested stream food webs (Wallace et al., 1997; Dudgeon and Wu, 1999). Food webs have also been shown to be dynamic, with taxa, links and aspects of structure changing over time and space, as demonstrated for freshwater systems by Warren (1989), Close and Lake (1994), Tavares-Cromar and Williams (1996), Thompson and Townsend (1999) and Woodward et al. (2005b).

In agricultural landscapes we might expect that in-stream primary production will provide the main support of the aquatic invertebrate community. For example, Bunn et al. (1997) studied in-stream ecosystem processes in a tropical lowland stream in far north Queensland by measuring community metabolism and analysing stable isotopes. The stream catchment had been extensively cleared for the cultivation of sugarcane, and in the absence of riparian shading, aquatic and semi-aquatic macrophytes choked the stream channel. They observed that stream metabolism switch between autotrophic and heterotrophic metabolism depending on cloud cover. On cloudy days dissolved oxygen become depleted especially at the stream bottom resulting in anoxia. Stable-isotope data indicated that little of the primary production from sugar cane or other $\mathrm{C}_{4}$ plant was transferred into the aquatic food web. The only significant contribution of $\mathrm{C}_{4}$ carbon was to the diets of some larger predatory fish, which must be directly dependent on terrestrial prey. In conclusion they stated that in the absence of significant riparian inputs of $\mathrm{C}_{3}$ carbon, it appears that in-stream primary production supported the aquatic invertebrate community. In New Zealand Hicks (1997) conducted a study of stable isotope of carbon and nitrogen comparing forested and pasture stream communities in the Waikato region and showed that food webs in the shaded forest streams were based on allochthonous material (conditioned leaf litter and terrestrial invertebrates). In contrast autotrophs in the forested streams did not contribute significantly to the $\mathrm{C}$ source of the food web, instead, the $C$ source of food webs in the unshaded pasture streams were a mixture of allochthonous and autochthonous material. Conditioned leaf litter appeared to have contributed to the pasture stream food webs, and the $\delta^{13} \mathrm{C}$ and $\delta^{15} \mathrm{~N}$ of some samples of epilithic diatoms indicated their consumption by invertebrates in pasture streams. Subsequently, Thompson and Townsend (2004) compared forest and grassland streams in order to determine the food web structure in relation to energy availability, spatial heterogeneity and ecosystem size with reference to riparian land use. They found that forested streams showed lower algal productivity and higher standing crops of organic matter than the grassland streams. Grassland sites showed a positive relationship 
between algal productivity and food chain length, whereas forest sites displayed a positive relationship between ecosystem size and food chain length. Therefore, algal production and organic matter standing crop were important determinants of invertebrate biomass and overall food-web structure. According to March et al. (2003) the dominant consumers in tropical island streams are often omnivorous freshwater shrimps that consume algae, leaf litter, insects, and other shrimps. Stable isotope analysis was used to investigate the relative importance of terrestrial and algal-based food resources to shrimps and other consumers and to determine, if the relative importance of these food resources changed along the stream continuum. They sampled $\delta^{15} \mathrm{~N}$ and $\delta^{13} \mathrm{C}$ signatures of leaves, algae, macrophytes, biofilm, insects, snails, fishes, and shrimps at three sites along the Río Espíritu Santo, Puerto Rico. Their results indicated that signatures of basal resources were distinct at all sites, and twosource $\delta^{13} \mathrm{C}$ mixing models suggested that shrimps relied more on algal-based carbon resources than terrestrially derived resources at all three of their sites. Their study supported the view that algal-based resources in tropical streams are very important to stream consumers, even in small forested headwater streams.

Gradient approaches have been used successfully in the study of food webs and take advantage of environmental shifts that occur along a gradient of natural systems. For example, a gradient approach was used effectively to understand the role of disturbance and resource supply in driving food-web structure in New Zealand streams (Townsend et al., 1998). Other studies have used gradient approaches to assess how freshwater food webs change through time and space (Olesen et al., 2010; Layer et al., $2010 \mathrm{~b}$ ), and in response to resource availability (RosiMarshall and Wallace, 2002), climate (Layer et al., 2010a; Layer et al., 2010b; Layer et al., 2011), disturbance (Parker and Huryn, 2006) and eutrophication (Rawcliffe et al., 2010).

Gut content analyses have been included in numerous studies of stream food webs to categorize the nature of materials ingested by invertebrates and fish. However, although gut content analyses provides an immediate picture of food recently ingested, they do not indicate whether the ingested materials are digested or assimilated (Rounick et al., 1982). In contrast stable isotope mixing models can sometimes be used to determine the contributions of food types (e.g., autochthonous and allochthonous organic matter) to an animal's diet (Phillips, 2001). Thus in the simplest mixing models two food sources can be partitioned using their stable carbon signatures (Phillips, 2001).

\section{METHODS}

\section{Study sites}

The study was carried out on the Mambilla Plateau, in the south east corner of Taraba State, Nigeria (110 - $6^{\circ}$ $\mathrm{E}$ and $6^{\circ}-7^{\circ} \mathrm{N}$ ). The Plateau has a tropical montane climate. Sampling was undertaken between October 2016 and January 2017. Nine streams (second and third order) were sampled; three in forest, three in tea plantations and three in maize fields, respectively. The forested sites were within mature submontane forest in the Ngel-Nyaki Forest Reserve). Maize and tea farming are common on the Mambilla Plateau, the tea plantations being well established crops. However, cultivation of maize in the study catchments started in 2008 and since then crop planting and livestock grazing have alternated on a yearly basis (i.e., shifting cultivation). The maize crop is rarely planted right up to the stream margins and grass or shrubs form riparian buffer zones up to approximately $50 \mathrm{~m}$ wide between the crops (Fig. 1).

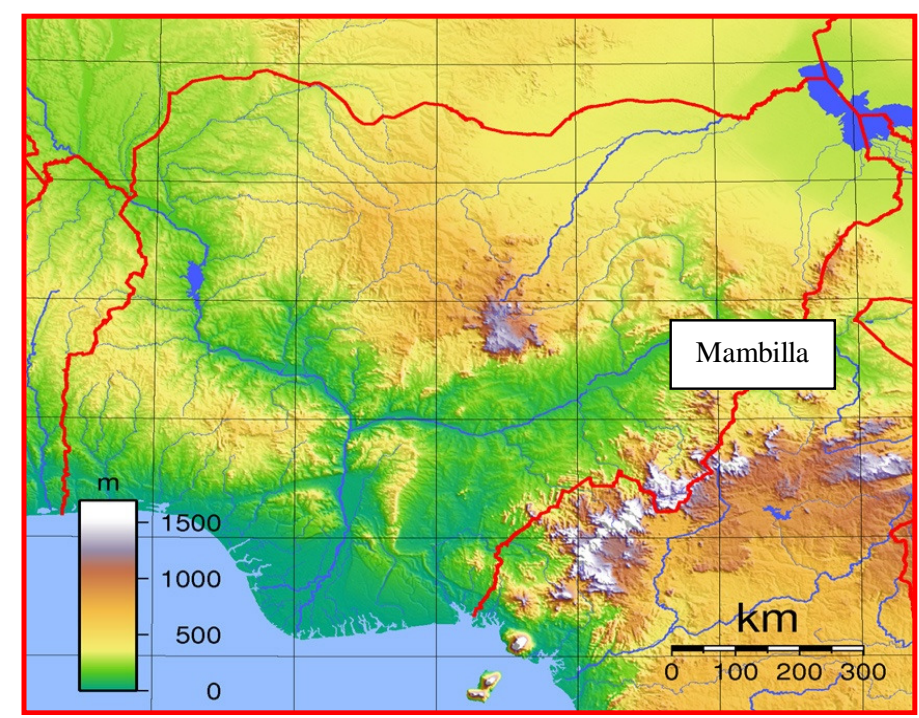

Figure 1: Location of sampling sites within the study area

near Ngel-Nyaki Forest Reserve, Mambilla Plateau, Taraba State, Nigeria. Vegetation of Nigeria (White, 1983) 
Trees were native Afromontane species (Deinbollia pinnata, Santiria trimera, Rafania sp., Croton macrostachyus, Anthonotha noldeae, Acacia senegalensis, Polyscios fulva, Syzygium guineense, Beilschmedia sp., Pouteria altissima and Bridelia speciosa). Bank-full stream width ranged from 4 to 12 $\mathrm{m}$ and substrate ranged from sand to large boulders. Basic water chemistry was similar in all nine streams; $\mathrm{pH}$ was 5.6-7.8, specific conductivity $30-110 \mu \mathrm{S} 25$ $\mathrm{cm}^{-1}$ and oxygen 56-80-\% saturation (using digital multi-function meter, model YSI: 63-10 FT John Morris Scientific Ltd).

\section{Basal food resources - algae \& detritus}

Basal food resources (source of carbon derived from terrestrial or in-stream producers) including fine particulate organic matter (FPOM) and algae were sampled for biomass and stable isotopes analyses. A single FPOM sample was collected from the water column at each site using plankton net (60 $\mu \mathrm{m}$ mesh), which was deployed for approximately ten minutes to collect enough material for analysis (approx. 1-2 gm DW). The FPOM sample was filtered through Advance GC50 glass fibre filters ( $0.5 \mu \mathrm{m}$ pores size), oven-dried at $60^{\circ} \mathrm{C}$ for $48 \mathrm{~h}$, and weighed. Filters were then ashed following Benfield (1996). Additional FPOM samples were collected for stable isotope analysis following the same procedure. After filtration, the latter samples were oven-dried and ground with a pestle and mortar. For each stream, biomass of CPOM was extracted from four benthic samples taken with a hand net (30 $\mathrm{cm} \times 30 \mathrm{~cm}, 500 \mu \mathrm{m}$ mesh size). Inorganic substrates were separated from CPOM by hand-picking. Dry mass (DM) and ash-free dry mass (AFDM) of each litter sample were determined following Benfield (1996), and a single ground sample from each stream was analysed for $\delta^{15} \mathrm{~N}$ and $\delta^{13} \mathrm{C}$. Benthic algal biomass was obtained by scraping five randomly selected stones $\left(50 \mathrm{~mm}^{2}\right.$ each) from the stream bed using a wire brush and washing the composite slurry into pottles. These samples were later filtered using a syringe and filter paper (Whatman glass microfiber filters $0.75 \mu \mathrm{m}$ pore size, $50 \mathrm{~mm}$ diameter disks) dried and weighed in the laboratory to $(0.01 \mathrm{mg})$. For stable isotope analysis sample of filamentous algae were collected by hand, and transported in water to the laboratory. After drying, each sample (57-256 mg DM) was ground with a pestle and mortar prior to analysis of stable isotope values.

\section{Benthic invertebrates and fish}

Fish and benthic invertebrates were collected from riffles during the dry seasons (October to March) of 2016 and 2017. Benthic invertebrates were collected from 15 cobbles and boulders in riffles in each stream $(n=45$ cobbles and boulders/treatment; cobbles and boulders diameters $4-35 \mathrm{~cm}$ ) with a triangular hand net (200-400 $\mu \mathrm{m}$ mesh) placed immediately downstream. Invertebrates were placed in Eppendorf tubes, which were taken to the laboratory on ice containers. Two common species of fish, Tilapia zilli (Cichlidae) and Clarias lazera (Clariidae) were collected from pools with a hand net and used for gut content analysis and stable isotope determination. Samples collected for gut content analyses were frozen and preserved later in $70 \%$ ethanol.

In the laboratory most benthic invertebrates were identified to family level and some to subfamily or lower. Only the most numerous taxa in each family was used in analyses. Between five to 20 individuals of common consumer taxa were gutted and examined for food contents. All predatory invertebrates and fish taxa collected were examined for gut contents, the numbers of individuals of each ranging from 10 to 15 . If large numbers of individuals of a particular taxon were available (e.g., the oligoneuriid mayfly Elassoneuria), three to five individuals of up to three size classes were examined to assess variation in feeding with animal size. Guts of invertebrates were removed, mounted on slides in lactophenol-PVA stained with lignin pink, and examined under a Nikon SMZ 800 stereo dissecting microscope at up to $400 \times$ magnification. Up to 10 fields were examined on each slide with a gridded graticule inserted in the eyepiece. At each grid crosshair, the four nearest food items were identified until 200 items had been identified on a slide. However, fewer than 100 items were identified on some slides from almost empty guts. Gut contents were categorised as filamentous algae, diatoms, fungi, CPOM $\geq 1 \mathrm{~mm}$ (usually leaf litter, wood, and gravel), FPOM $<1 \mathrm{~mm}$ (usually amorphous detritus) and animal parts. Most prey items were identified to family using slides and the drawings in Dudgeon (1999). The relative abundance of each category of prey type was calculated.

\section{Stable isotope analyses}

In the laboratory invertebrates were kept alive in bottles of water for $\sim 15$ hours to clear guts before freezing (Cummins, 1973; Parkyn et al., 2001) and were later rinsed with distilled water to remove nonanimal material (e.g., detritus). Digestive tracts of the crab (Brachyura; Potamonautidae) were removed to avoid contamination by non assimilated materials. Snails were decalcified with $1 \mathrm{~N} \mathrm{HCL}$ and rinsed in distilled water several times as in Mantel (2004). Samples of lateral muscle tissue $\geq 100 \mathrm{mg}$ DM were taken from fishes, being careful to avoid bones and scales. Plant samples were rinsed and handpicked to remove biofilm, detritus and invertebrates. All samples were oven dried at $60^{\circ} \mathrm{C}$ for $48 \mathrm{~h}$, ground to a fine powder with a mortar and pestle, weighed and stored in Eppendorf tubes. In order to avoid contamination all grinding equipment were cleaned using $100 \%$ ethanol and Kim wipes before the grinding of a new sample. Subsamples of all animal (c. $1 \mathrm{mg} \pm 0.15 \mathrm{DW}$ ) and plant samples (algae, CPOM, moss) (c. 3mg DW) were used for analysis. Each individual sample was weighed to $0.1 \mathrm{mg}$. Each sample was transferred to an $8 \mathrm{~mm} \times 5 \mathrm{~mm}$ tin capsule using a clean spatula. Tin capsules were placed in a 96-well plastic culture tray, and sent to the stable isotope facility, University of 
California, Davis. Results (\%o) are reported as $\delta^{13} \mathrm{C}$ and $\delta^{15} \mathrm{~N}$, i.e., the difference between the sample and an international standard (air for $\mathrm{N}$ and Peedee Belemnite for C. Analytical precision was $0.3 \%$.

\section{Properties of food webs}

A range of food web attributes were calculated using gut content data following methods in Mantel (2004): species richness (or web size, S); number of links (or number of "ones" in the food web matrix, L); mean and maximum length of all food chains; fraction of basal species (species with no prey, i.e., basal food resources); fraction of intermediate species (species that have predators and prey); fraction of top predators not preyed upon; fraction of omnivores (animals feeding at $>1$ trophic level); predator-prey ratio (number of predators divided by number of prey); trophic connectance $\left(\mathrm{CT}_{\mathrm{T}}=\mathrm{L} / \mathrm{S}[\mathrm{S}-1 \mathrm{]}\right.$; realised connectance (CR)

$$
\begin{aligned}
& \mathrm{CR}=\mathrm{L} /\left\{\mathrm{S}^{2}-[(\{\mathrm{pp}+\mathrm{ba}] \mathrm{S})+(\mathrm{S}-\{\mathrm{pp}+\mathrm{ba}])+\right. \\
& (\mathrm{pr}\{\mathrm{pp}+\mathrm{ba}])(\text { Jaarsma et al., 1998). }
\end{aligned}
$$

The predator-prey ratio was calculated such that 'preys' are primary consumers and predators are 'any species that eat prey even if they themselves are preyed upon'. The prey-predator ratio was also calculated by dividing the sum of the intermediate and basal species in the web by the sum of the top and intermediate species. Biplot of $\delta^{13} \mathrm{C}$ and $\delta^{15} \mathrm{~N}$ values of FPOM/CPOM, algae, benthic invertebrates, and fish were used to compare patterns of isotopic variation within and between sites (forest, tea plantation and maize). Given that $\delta^{13} \mathrm{C}$ values of dietary items are usually conserved within $1 \%$ o in consumer tissues (McCutchan et al., 2003), the relative importance of alternative source of organic carbon assimilated can be assessed by the relative position of the consumer and potential food sources on the $x$ axis of the bi-plot. In contrast to carbon isotopes, nitrogen isotope ratios of consumer tissues typically are $2.5-3.4 \%$ o higher than tissues of their food items (McCutchan et al., 2003), enabling $\delta^{15} \mathrm{~N}$ to serve as a rough indicator of trophic position in addition to refining estimates of source contributions based on $\delta^{13} \mathrm{C}$ values (Winemiller et al., 2011).

\section{RESULTS}

\section{Basal food resources - algae and detritus}

Significant differences in the biomass of CPOM and algae, but not FPOM were found among streams with differing land uses. CPOM was significantly higher in forest than tea plantation and maize fields' streams, whereas, forested streams had the lowest algal biomass and maize streams the highest (Table 1).

Table 1: Mean biomass ( $\pm \mathrm{SE}, \mathrm{n}=3$ streams per land use) of basal food resources in streams across three land uses. FPOM = fine particulate organic matter, CPOM = coarse particulate organic matter, * indicates significant difference $p<0.05$ and ${ }^{* *} p<0.01$

\begin{tabular}{lccccc}
\hline Sites & Forest & Tea & Maize & F - stat & P - value \\
\hline FPOM $(\mathrm{g} / \mathrm{L})$ & $4.0(1.3)$ & $3.0(0.2)$ & $1.3(0.1)$ & 0.187 & 0.834 \\
CPOM $\left(\mathrm{g} / \mathrm{m}^{2}\right)$ & $6.0(1.0)$ & $3.2(0.3)$ & $2.0(0.2)$ & 8.727 & $0.016^{*}$ \\
Algae $\left(\mathrm{DW} \mathrm{g} / \mathrm{m}^{2}\right)$ & $2.2(0.3)$ & $3.0(1.0)$ & $5.0(0.4)$ & 37.599 & $<0.001^{* *}$ \\
\hline
\end{tabular}

\section{Gut contents}

Eight benthic invertebrate taxa and two fish species were used for gut analysis. They represented $75 \%$ of the total benthic invertebrates collected. Only two taxa that were found in high numbers in all three land use system; snail Melanoides tuberculata (Thiaridae) and gyrinid beetles (Table 2). The gut contents of the snail differed between forest, tea plantation and maize field streams. Individuals from the forest streams had guts filled with FPOM (65\%) and diatoms (3\%) and those from the tea plantation and maize sites had filamentous algae as the dominant food items (80\%) with smaller amounts of diatoms (10\%). The gyrinid beetles had a smaller mixed diet in all three land uses dominated by FPOM, diatoms and animal parts, especially Chironominae.

The Oligoneuriid mayfly was very abundant in forested streams and also collected in tea plantation streams. Its diet was similar in both land uses and was dominated by FPOM, and diatoms, indicating it may be a filter-feeder (Table 2). 
Table 2: Dominant food found in the guts of each taxon within land use $(R=$ rare, $<5 \%$; $C=$ common, $5-$ 20\%; $A$ = abundant, $>20 \%$ ). $-=$ absent. Prey - indicates invertebrate prey taxa able to be identified in guts

\begin{tabular}{llcccccc}
\hline Land use & Consumer & \multicolumn{6}{c}{ Dominant food resources } \\
\cline { 3 - 7 } & Gomphidae & - & $\mathrm{R}$ & - & $\mathrm{R}$ & $\mathrm{C}$ & Chironomidae \\
\hline Forest & GPOM & FPOM & Fil. algae & Fungi & Diatoms & \\
& Gyrinidae & - & $\mathrm{C}$ & $\mathrm{R}$ & - & $\mathrm{R}$ & Hydropsychidae \\
& Hydropsychidae & - & $\mathrm{R}$ & $\mathrm{A}$ & $\mathrm{R}$ & $\mathrm{C}$ & - \\
& Oligoneuriidae & - & $\mathrm{A}$ & $\mathrm{R}$ & $\mathrm{R}$ & $\mathrm{C}$ & - \\
& Perlidae & - & $\mathrm{C}$ & - & - & $\mathrm{R}$ & Chironominae \\
& Potamonautidae & $\mathrm{C}$ & $\mathrm{C}$ & - & $\mathrm{R}$ & $\mathrm{R}$ & - \\
& Tipulidae & $\mathrm{A}$ & $\mathrm{R}$ & - & $\mathrm{R}$ & $\mathrm{C}$ & - \\
& M. tuberculatus & $\mathrm{A}$ & $\mathrm{A}$ & $\mathrm{R}$ & $\mathrm{C}$ & $\mathrm{C}$ & - \\
& Tilapia zilli & - & $\mathrm{C}$ & - & - & $\mathrm{R}$ & Perlidae \\
& Clarias lazera & & $\mathrm{C}$ & - & - & $\mathrm{R}$ & Perlidae \\
& Gyrinidae & - & $\mathrm{R}$ & $\mathrm{R}$ & - & $\mathrm{R}$ & Chironominae \\
& Hydropsychidae & - & $\mathrm{A}$ & $\mathrm{C}$ & $\mathrm{R}$ & $\mathrm{C}$ & - \\
& Oligoneuriidae & - & $\mathrm{C}$ & $\mathrm{R}$ & $\mathrm{R}$ & $\mathrm{C}$ & - \\
& M. tuberculatus & $\mathrm{R}$ & $\mathrm{C}$ & $\mathrm{A}$ & $\mathrm{A}$ & $\mathrm{C}$ & - \\
& Tilapia zilli & - & $\mathrm{B}$ & $\mathrm{C}$ & $\mathrm{C}$ & $\mathrm{R}$ & Baetidae \\
& Clarias lazera & - & $\mathrm{B}$ & $\mathrm{C}$ & $\mathrm{C}$ & $\mathrm{R}$ & Perlidae \\
& Gomphidae & - & $\mathrm{R}$ & $\mathrm{C}$ & - & $\mathrm{R}$ & Chironomidae \\
& Gyrinidae & - & $\mathrm{C}$ & $\mathrm{C}$ & - & $\mathrm{R}$ & - \\
& Potamonautidae & $\mathrm{R}$ & $\mathrm{C}$ & $\mathrm{C}$ & $\mathrm{R}$ & $\mathrm{C}$ & Hydropsychidae \\
& Tipulidae & - & $\mathrm{C}$ & $\mathrm{C}$ & $\mathrm{R}$ & $\mathrm{C}$ & - \\
& M. tuberculatus & - & $\mathrm{C}$ & $\mathrm{A}$ & $\mathrm{A}$ & $\mathrm{C}$ & - \\
& Tilapia zilli & - & $\mathrm{C}$ & $\mathrm{A}$ & $\mathrm{C}$ & $\mathrm{A}$ & Chironomidae \\
& Clarias lazera & - & $\mathrm{C}$ & $\mathrm{B}$ & $\mathrm{B}$ & $\mathrm{A}$ & Chironomidae \\
\hline
\end{tabular}

Similarly the filter feeding hydropsychid caddisflies (of which there were at least two distinct species) were also common in forested streams. Again in both land uses they had a mixed diet of FPOM (45\%) and diatoms $(25 \%)$. In contrast, the gut contents of perlid stoneflies, which were found in the forested streams, were dominated by animal prey (50-90\%, primarily hydropsychids) indicating they were predators. In forested streams their gut contents were dominated by FPOM (10\%) and CPOM (80\%) of which $10 \%$ was wood and $70 \%$ leaves. The guts of the gomphid dragonflies were dominated by animal fragments $(70 \%)$, most of which were well fragmented and difficult to identify, although Chironominae seemed an important prey $(20 \%)$. Dragonfly guts also commonly contained FPOM (10\%) and diatoms (10\%), although these may have been accidentally ingested or in the invertebrate prey they consumed. The tipulid Leptotarsus (Tipulinae) ingested mainly CPOM (90\%) $80 \%$ of which comprised leaf fragments and $10 \%$ wood in forested streams. FPOM and algae were common in maize streams. Leptotarsus seemed to be an important shredder. The two fish species Clarias lazera and Tilapia zilli consumed mainly animals (40$80 \%$ relative abundance) but also some CPOM. Dissected fish contained an average of three prey items per gut, predominantly mayfly and stonefly larvae (55-60\%) (Table2).

Stable isotope values of basal food resources- algae and detritus

Biplots of $\delta^{13} \mathrm{C}$ and $\delta^{15} \mathrm{~N}$ for basal food resources collected from riffles in forest, tea plantation and maize streams showed that FPOM was depleted in $\delta^{13} \mathrm{C}$ enriched in $\delta^{15} \mathrm{~N}$ in forested streams compared to tea and maize streams (Fig. 2). For CPOM mean $\delta^{13} \mathrm{C}$ and $\delta^{15} \mathrm{~N}$ values were intermediate in maize and tea streams but less enriched in forested streams (Fig. 2). Algae showed no difference in $\delta^{15} \mathrm{~N}$ between land uses, however again forested streams were depleted in $\delta^{13} \mathrm{C}$. 


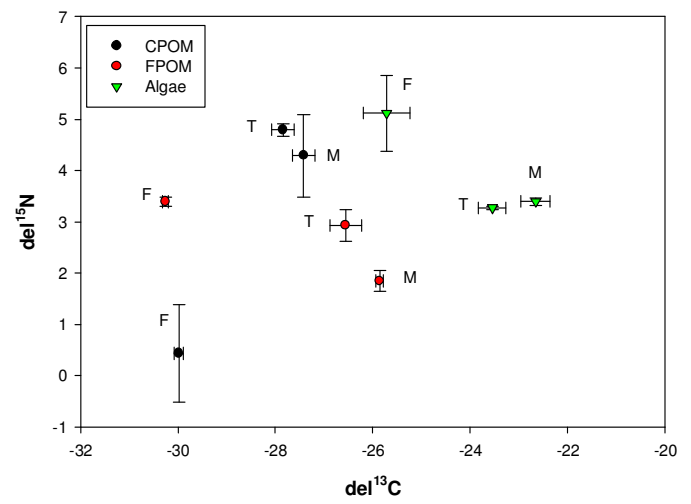

Figure 2: $\delta^{13} \mathrm{C}$ and $\delta^{15} \mathrm{~N}$ biplots of algae, FPOM and CPOM collected from riffles in streams flowing through; $F=$ continuous forest, $T=$ tea plantation $=$ and $M=$ maize field on the Mambilla Plateau. Mean $\pm S E, n=3$

Stable isotope signatures of primary and secondary consumers

For primary consumers (e.g., snails, mayflies and tipulids) $\delta^{13} \mathrm{C}$ and $\delta^{15} \mathrm{~N}$ signatures were generally similar, with $\delta^{13} \mathrm{C}$ values varying little between consumers in differing land uses (Fig. 3). One notable exception was the mayflies which were highly enriched in $\delta^{15} \mathrm{~N}$ in forested streams consistent with the high $\delta^{15} \mathrm{~N}$ signature of FPOM and algae in these systems and with filter feeding by the mayfly Elassoneuria. In contrast, the snails in maize streams had the lowest $\delta^{15} \mathrm{~N}$ (Fig. 3).

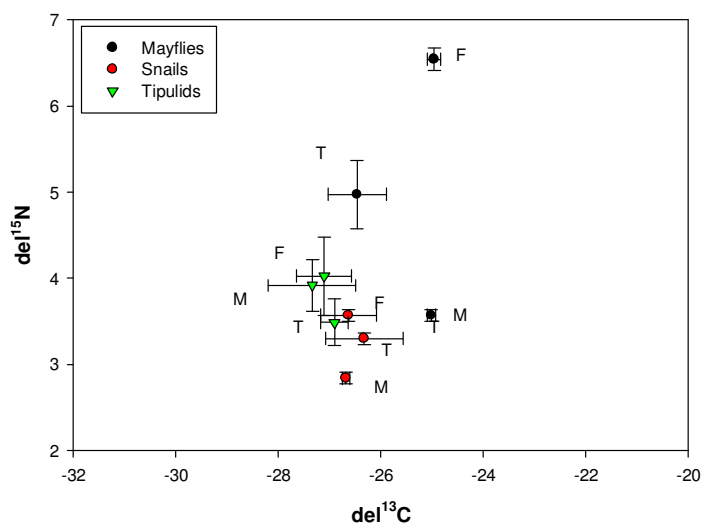

Figure 3: Stable isotope biplots of primary consumers collected from riffles in streams flowing through; forest =

$\mathrm{F}$, tea plantation $=\mathrm{T}$ and maize field $=\mathrm{M}$. Values are mean $\pm S E, n=3$

For the main predators and omnivores (dragonfly larvae, crabs and fish) considerable overlap occured between species across land uses (Fig. 4). 


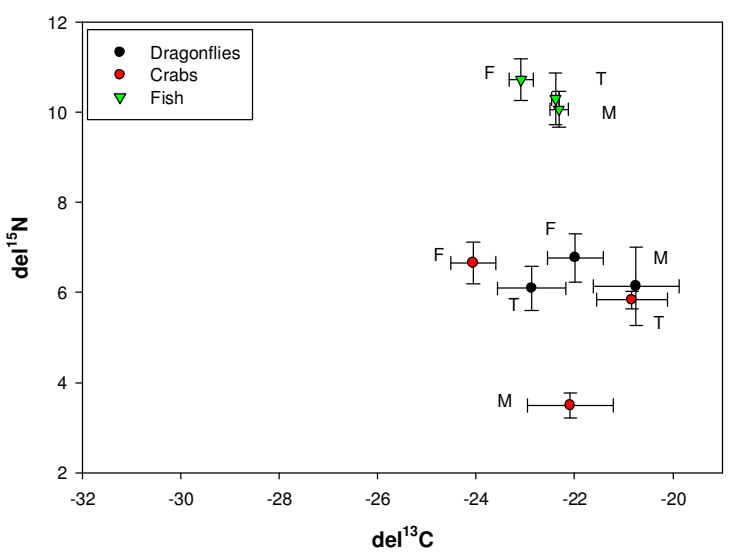

Figure 4: Stable isotope biplots of predators and omnivores (dragonflies [Gomphidae] and fish) and a macro-shredder (potamonautid crab) collected from riffles in streams flowing through; forest $=F$, tea plantations $=\mathrm{T}$ and maize fields $=\mathrm{M}$. Values are mean \pm $\mathrm{SE}, \mathbf{n}=\mathbf{3}$

\section{Mixing model}

A mixing model analysis for consumer taxa from each stream indicated forested stream consumers were tightly distributed but more variable in tea and maize plantation streams. Because the $\delta^{13} \mathrm{C}$ signatures of algae and leaves overlapped strongly in the forested and tea plantation streams the mixing model was not able to determine the relative importance of the two food sources in the diets of consumers. However, because $\delta^{15} \mathrm{~N}$ signatures of consumers tended to be more aligned to those of leaves, this suggests a greater use of allochthonous food sources in all three stream types. The proportions of algae and leaves incorporated by consumers as estimated by the mixing models confirm that algae appear to be less important than leaves, although comparison of the credibility intervals (data not shown) indicated the evidence is not strong. Interestingly, the predatory taxa, dragonflies and fish, were supported more strongly by algal-based webs.

\section{Web properties}

Food web attributes differed significantly between land uses (Table 3). Forested streams had significantly larger food webs (a mean of 26 taxa) compared to tea and maize which had means of 17 and 16 taxa, respectively (Table 3).

Similarly the number of links (L) were also, highest in the forest (mean 183) followed by the tea plantation (mean of 114) whereas in maize fields it was lowest (mean 79). Maximum chain length (MCL) was similar for both forest and tea plantations (mean 3) but differed with maize field (mean 2). Predator: prey ratio was highest in maize field streams (mean 4) but little difference was observed between forested streams and tea plantation streams. Trophic connectance (CT), realized connectance (CR) and linkage density (L/S) did not differ between the three (forest, tea plantation and maize fields) stream types. However, linkage complexity (SCR) differed significantly in the three streams $\left(F_{2,6}=8.812, P=0.016\right.$, Table 3$)$.

Fish had strongly enriched $\delta^{15} \mathrm{~N}$ signatures (10-12\%o), which overlapped among land use types. In contrast, $\delta^{13} \mathrm{C}$ values were similar although forested stream fish were slightly depleted in $\delta^{13} \mathrm{C}$ (Fig. 5). Of the other taxa, the crabs in tea plantations had markedly lower $\delta^{15} \mathrm{~N}$ signatures indicating greater consumption of algae and FPOM in these streams. The isotope signatures of the predators and omnivores integrate dietary pathways within food webs and the results indicate they fed on a variety of prey consuming varying amount of allochthonous and autochthonous carbon.

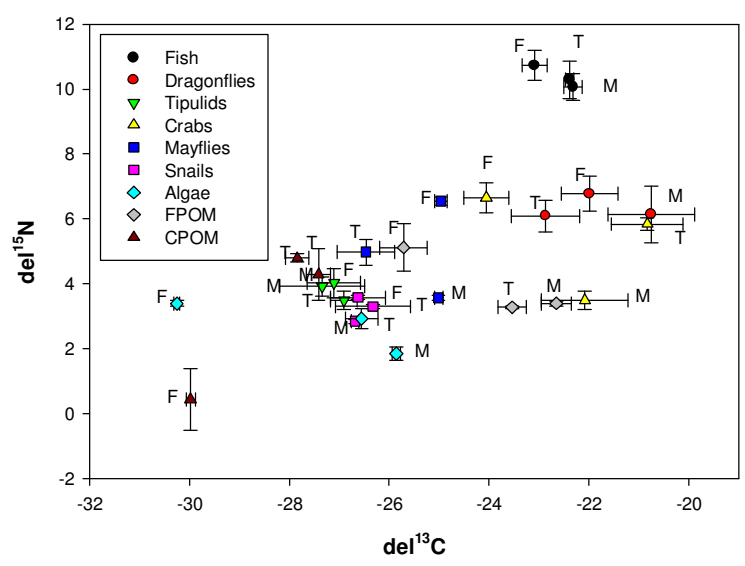

Figure 5: Stable isotope bi-plots for all primary and secondary Consumers collected from riffles in streams flowing through forest, tea plantations and maize fields on Mambilla Plateau. Values are mean $\pm S E, n=3$. 
Table 3: Food web properties for each stream group on the Mambilla Plateau calculated from the gut content analyses and kick sample collected from nine streams. Values shown are group means $( \pm S E)$ and ranges, $n=3$ streams per type. *: Indicate significant difference $(P<0.05)$ ANOVA.

\begin{tabular}{|c|c|c|c|c|c|c|c|c|}
\hline \multirow{2}{*}{$\begin{array}{l}\text { Stream type } \\
\text { Food web attributes }\end{array}$} & \multicolumn{2}{|l|}{ Forest } & \multicolumn{2}{|l|}{ Tea } & \multicolumn{2}{|l|}{ Maize } & \multirow[t]{2}{*}{ F-stat } & \multirow[t]{2}{*}{ P-value } \\
\hline & Mean \pm SE & Range & Mean \pm SE & Range & Mean \pm SE & Range & & \\
\hline Web size $(\mathrm{S})$ & $26 \pm 2.02$ & $23-28$ & $17.0 \pm 2.02$ & $15-20$ & $16.06 \pm 1.20$ & $15-20$ & 15.509 & $0.004 * *$ \\
\hline No. of linkages (L) & $183.06 \pm 28.01$ & $140-234$ & $114.06 \pm 20.05$ & $80-148$ & $79.33 \pm 13.09$ & $60-104$ & 6.347 & $0.033 *$ \\
\hline Max. food chain length (MCL) & $3 \pm 0.00$ & $3.0-3.0$ & $3 \pm 0.0$ & $3-3$ & $2.66 \pm 0.33$ & $2-3$ & 1 & 0.421 \\
\hline Fraction of basal species & $0.17 \pm 0.02$ & $0.14-0.21$ & $0.25 \pm 0.03$ & $0.19-0.21$ & $0.20 \pm 0.01$ & $0.18-0.22$ & 2.776 & 0.14 \\
\hline Fraction of intermediate species & $0.72 \pm 0.03$ & $0.65-0.78$ & $0.68 \pm 0.03$ & $0.64-0.76$ & $0.74 \pm 0.03$ & $0.68-0.78$ & 0.646 & 0.556 \\
\hline Fraction of top predators & $0.09 \pm 0.02$ & $0.04-0.13$ & $0.05 \pm 0.01$ & $0.04-0.06$ & $0.05 \pm 0.03$ & $0.05-0.11$ & 0.888 & 0.459 \\
\hline Predator: prey ratio & $1.36 \pm 0.07$ & $1.5-1.35$ & $3.0 \pm 0.2$ & $2-3$ & $4.05 \pm 0.5$ & $3.0-5$ & 17.337 & $0.003 * *$ \\
\hline Trophic connectance (CT) & $0.27 \pm 0.00$ & $0.17-0.46$ & $0.36 \pm 0.0 .03$ & $0.31-0.41$ & $0.25 \pm 0.05$ & $0.19-0.37$ & 0.819 & 0.484 \\
\hline Realized connectance (CR) & $0.04 \pm 0.1 .72$ & $0.03-0.05$ & $0.06 \pm 0.01$ & $0.04-0.07$ & $0.05 \pm 00$ & $0.05-0.06$ & 2.384 & 0.172 \\
\hline Linkage density (L/S) & $6.72 \pm 0.02$ & $4.82-10.2$ & $7.07 \pm 0.44$ & $6.61-7.91$ & $4.8 \pm 5.77$ & $3.89-6.33$ & 1.189 & 0.367 \\
\hline Linkage complexity (SCR) & $3.07 \pm 0.37$ & $2.4-4$ & $2.28 \pm 0.03$ & $1.11-2.31$ & $1.29 \pm 0.10$ & $1-2.21$ & 8.812 & $0.016^{*}$ \\
\hline
\end{tabular}




\section{DISCUSSION}

Streams in all three land uses included a range of basal food resources including FPOM, CPOM and algae and my gut analyses indicated that bacteria and fungi were also common. Not surprisingly, CPOM biomass was significantly higher in the forested streams than in the other land uses whereas algal biomass was significantly higher in the maize streams. The food webs of forested, tea plantation and maize field streams on the Mambilla Plateau also incorporated an assemblage of insect crustacean and molluscan primary consumers, predatory insects, carnivorous fish and omnivorous crustaceans. There were a number of limitations in my food web calculations. The values estimated for all three food webs will have been affected by limitations in the taxonomic resolution for different taxonomic groups. For example, I was not able to identify and count different diatoms, filamentous and other algal taxa within each food web. Furthermore, my benthic invertebrate identifications were limited by poor taxonomic knowledge. However, my results fall within the range reported by Mantel et al. (2004) and Dudgeon et al. (2010).

Regardless of these issues our data show that the forested streams had more complex food webs due to greater numbers of taxa at multiple trophic levels. Forested streams had longer food-chain lengths, higher fractions of top predators and predatorprey ratios than in tea plantation and maize field streams. Gut content analyses showed that FPOM, filamentous algae and diatoms were all significant basal food resources in the forest, tea plantation and maize streams, whereas CPOM was only important in forested streams. The high degree of autochthony observed in the non-forested streams is consistent with findings from a number of tropical streams elsewhere (Bunn et al., 1999; March and Pringle, 2003; Douglas et al., 2005; Brito et al., 2006; Jacobsen et al., 2008) and is also typical of larger temperate streams and other sites where canopy cover is reduced (Finlay, 2001; Finlay et al., 2002).

The importance of CPOM in our forested streams is consistent with many other studies. Allochthonous material (CPOM and FPOM) was the primary basal food source in food webs of a forested head water stream on Bougainville Island, Papua New Guinea (Yule, 1996), in a third order grassland stream in New Zealand (Jaarsma et al., 1998), and in forested streams in the Appalachians Mountains, USA (Hall et al., 2000). FPOM, presumably of allochthonous origin, was the major dietary component of consumers in Broadstone stream, a second order stream in southern England (Lancaster and Robertson, 1995; SchmidAraya et al., 2002), and in a forested third order stream in Ontario Canada (Travares-Cromar and Williams, 1996). However, in a forested Sri Lankan stream Costa and Fernando (1967) found that algae dominated the gut contents of benthic invertebrates, although some fish species and larvae of a psephenid beetle, Eubrianax sp., ingested leaf litter.
Studies of stable isotope signatures have shown the importance of autochthonous resources to Ephemeroptera in forested streams in Hong Kong (Salas and Dudgeon, 2001) and more generally to food webs in forested as well as open-canopied streams and rivers (Rosenfield and Roff, 1992; Benfield, 1996; March and Pringle, 2003). The selection of less abundant algal resources might be based on their higher food quality, in terms of energy and protein content (Bowen et al., 1995; Friberg and Jacobsen, 1999), and the easier digestion of algae compared with most aquatic macrophytes and leaf litter (Wallace et al., 1987; Whitledge and Rabeni, 1997; Rabeni et al., 2002) The dominance of oligoneuriid mayfly (Elassoneuria) which is probably a filter-feeder in forested streams resulted in FPOM being an important resource.

Omnivory appeared to be uncommon in the food webs of the three types of streams in my study on the Mambilla Plateau. Crabs were collected in forested streams, and were probably omnivorous, my gut content data showed ingestion of CPOM, FPOM and algae and limited animal fragments. However, the isotope data indicated they were enriched in $\delta^{15} \mathrm{~N}$ so they may also feed on primary consumers. On the other hand low amounts of animal prey ingested by crabs may reflect a genuine difference in food web dynamics between small streams and larger lowland tropical rivers. For example omnivory is widespread among consumers in large rivers with seasonal flow in tropical Australia and the Neotropics where food webs are dominated by relatively few strong interactors and macro-consumers that control energy flows through animal communities (Winemiller, 1990; Jepsen and Winemiller, 2002; Douglas et al., 2005; Coat et al., 2009). Given the scarcity of data on tropical stream food webs, and the potential for differences in food web attributes and energy flow between different-sized streams, the need for investigations on tropical streams similar to those undertaken on their temperate counterparts is evident (Dudgeon et al., 2010).

Comparisons of forested, tea plantation and maize streams indicated that the stable carbon and nitrogen ratios of basal food resources (CPOM and algae) and major consumers (dragonflies, craneflies, crabs, mayflies, snails and two benthic fish species) differed little between tea plantation and maize field sites, but showed greater differences with forested streams.

Based on the gut content analyses, the relative contributions of dominant food sources in the three stream types (forest, tea plantation and maize) showed that CPOM and FPOM were dominant in forested streams, whereas in the tea plantation streams filamentous algae and fungi dominated most consumers' guts. However, in maize field streams filamentous algae and fungi were more important as food sources for animals. The isotopic mixing models suggested greater use of allochthonous food, although the wide confidence interval apparent in the models makes it difficult to draw firm conclusions. Overall however, my result indicated that both allochthonous 
and autochthonous resources supported the aquatic invertebrate populations in all streams.

Overgrazing, wild fire, and bush clearing for farming have been major ecological problems on the Mambilla Plateau. Ultimately, we require a better understanding of how human disturbances such as habitat destruction affect reciprocal flows of invertebrates and other resource subsidies between linked stream and riparian habitats. Ecologists have long recognized that degradation of riparian habitat can alter flows of resources like leaves, wood, and dissolved organic carbon to stream ecosystems (e.g., Likens \& Bormann, 1974), but the impact of a reduction in terrestrial invertebrate fluxes to streams has rarely been considered (Likens and Bormann, 1974). Converting riparian forest to grassland (Kawaguchi and Nakano, 2001), the grazing of riparian zones (Young and Huryn, 1996) and changing the species composition of riparian vegetation (Mason and McDonald, 2006), can alter terrestrial invertebrate inputs to streams, thereby restructuring stream food webs (Baxter et al., 2004). However, riparian disturbance can also affect many other factors including light, temperature, and channel morphology, so research is needed to assess interactions between these and allochthonous inputs.

The present study was undertaken to determine whether a combination of stable isotope ratios and gut content analyses could provide measures of food web structure in tropical highland streams draining catchments in which land use differed. Our results tend to support generalizations made for other tropical stream ecosystems. In that, they were neither simple in trophic structure nor could they be characterised as having a limited array of feeding interactions. In contrast, feeding interactions in some tropical rivers are dominated by macro-consumers, and consequently have somewhat simplified feeding interactions (Dudgeon et al., 2010). Although macroconsumers (crabs) could be common at my sites, insect larvae and snails were the predominant primary consumers. Additionally, the results, especially gut analyses, suggested that autochthonous resources may have been of greater importance in supporting aquatic invertebrate populations in forested streams than appears to be the case in many small temperatezone forest streams, which are strongly dependent on allochthonous inputs (McLachlan and Ladle, 2009 and Jonsson et al., 2018). However, even though autochthonous resources may have been of great importance to invertebrate in the forested streams our result shows that algal biomass is much lower in these streams. This might have been due to constant grazing and rapid turnover of algal biomass.

\section{ACKNOWLEDGEMENTS}

We thank Prof. M.J, Winterbourn for identifying the fauna. Hayley Stoddart provided technical assistance in processing samples for the isotope analysis. Others who assisted in various ways include Stephen Pohe, Milen Marinov and Kristy Hogsden (University of Canterbury). Funding came from the University of Canterbury and Gombe State University Nigeria.

\section{REFERENCES}

Baxter, C. V., Fausch, K. D., Murakami, M. \& Chapman, P. L. (2004) Fish invasion restructures stream and forest food webs by interrupting reciprocal prey subsidies. Ecology, 85, 2656-2663.

Benfield, E. F. (1996) Leaf breakdown in stream ecosystems. Pages 579-589 in Hauere, F. R. and Lamberti, G.A. (editors). Methods in stream ecology. Academic Press, San Diego, California.

Brett, M.T., Bunn, S.E., Chandra, S. Et al.(2017). How important are terrestrial organic carbon inputs for secondary production in freshwater ecosystems? Freshwater Biology 2017;00:1-22. https://doi.org/10.1111/fwb.12909

Brito, E. F., Moulton, T.P., Souza, M. L. \& Bunn., S. E. (2006) Stable isotope analysis indicate microalgae as the predominant food source of fauna in a coastal forest stream, south-east Brazil. Austral Ecology, 31, 623-633.

Bunn, S. E., Davies, P.M. \& Mosich, T. D. (1999) Ecosystem measures of river health and their response to riparian and catchment degradation. Freshwater Biology, 41, 333-345.

Bunn, S. E., Davies, P. M. \& Kellaway, D. M. (1997) Contributions of sugar cane and invasive pasture grass to the aquatic food web of a tropical lowland stream. Marine and Freshwater Research, 48, 173 $-179$.

Cummins, K. W. \& Klug, M. J. (1979) Feeding ecology of stream invertebrates. Annual Review of Ecology and Systematics, 10, 147-172.

Douglas, M. M., Bunn, S. E. \& Davies, P. M. (2005) River and wetland food webs in Australia's wet-dry tropics: general principles and implication for management. Marine and Freshwater Research, 56, 329-342.

Dudgeon, D. (1982) An investigation of physical and biological processing of two species of leaf litter in Tai Po Kau forest stream, New Territories, Hong Kong. Archiv für Hydrobiologie, 96, 1-32.

Dudgeon, D. (2008) Tropical stream ecology. Academic Press, London.

Dudgeon, D., Cheung, F. K. W. \& Mantel., S. K. (2010) Food web structure in small streams: do we need different models for the tropics. Journal of the North American Benthological Society, 29, 395-412.

Dudgeon, D. \& Wu, K. K. Y. (1999) Leaf litter in a tropical stream food or substrates for macroinvertebrates? Archiv für Hydrobiologie, 146, 65-82.

Finlay, J. C. (2001) Stable-carbon-isotope- ratios of river biota: implications for energy flow in lotic food webs. Ecology, 82, 1052-1064.

Finlay, J. C., Khandwala, S. \& Power, M. E. (2002) Spatial scales of carbon flow in a river food web. Ecology, 83, 1845-1859.

Gessner, M. O., Chauvet, E. \& Dobson, M. (1999) A perspective on leaf litter breakdown in streams. Oikos, 85, 377-384.

Hall, R. O., Wallace, J. B. \& Eggert, S. L. (2000) Organic matter flow in streams food webs with 
reduced detrital resource base. Ecology, 81, 34453463.

Hicks, B. J. (1997) Food webs in forested and pasture streams in the Waikato Region, New Zealand: A study based on analyses of stable isotopes of carbon and nitrogen, and fish gut contents. New Zealand Journal of Marine and Freshwater Research, 31, 651-664.

Hogsden, K. L. \& Harding, J. S. (2012) Anthropogenic and natural sources of acidity and metals and their influence on the structure of stream food webs. Environmental Pollution, 162, 466-474.

Jaarsma, N. G., De Boer, C. R., Townsend, C. R., Thompson, R. M. \& Edwards, E. (1998) Characterising food-webs in two New Zealand streams. New Zealand Journal of Marine and Freshwater Research, 32, 271-286.

Jacobsen, D., Cressa, C., Mathooko, J. M. \& Dudgeon, D. (2008) Macroinvertebrates: composition, life histories and production. Academic Press, London: Pp. 66-106.

Jepsen, D. B. \& Winemiller, K. O. (2002) Structure of tropical river food webs revealed by stable isotope ratios. Oikos, 96, 46-55.

Jonsson, M., Polvi, L.E., Sponseller, R.A.and Stenroth, K. (2018). Catchment properties predict autochthony in stream filter feeders. Hydrobiologia http://doi.org/10.1007/s10750-018-3553-8

Kaushik, N. K. \& Hynes, H. B. N. (1971) The fate of the dead leaves that fall into streams. Archiv für Hydrobiologie, 68, 465-515.

Kawaguchi, Y. \& Nakano, S. (2001) Contribution of terestrial invertebrates to annual resource budget for salmonids in forest and grassland reaches of a headwater stream. Freshwater Biology, 46, 303316.

Lancaster, J. \& Robertson, A. L. (1995) Microcrustacean prey and macroinvertebrate predators in a stream food web. Freshwater Biology, 34, 123-134.

Lau, D. C. P., Leung, K. M. Y. \& Dudgeon, D. (2009) What does stable isotope analysis reveal about trophic relationships and the relative importance of allochthonous and authochthonous resource in tropical streams? A synthetic study from Hongkong. Freshwater Biology, 54, 127-141.

Layer, K., Hildrew, A. J., Jenkins, J. B., Ried, J. O., Rossiter, S. J. \& Townsend, C. R. (2011) Long-term dynamics of a well-characterised food web: four decades of acidification and recovery in the Broadstone Stream model system. Advances in Ecological Research, 44, 69-117.

Layer, K., Hildrew, A. J., Monteith, D. \& Woodwards., G. (2010a) Long-term variation in the littoral food web of an acidified mountain lake. Global Change Biology, 3, 242-245.

Layer, K., Riede, J. O., Hildrew, A. J. \& Woodwards., G. (2010b) Food web structure and stability in 20 streams across a wide $\mathrm{pH}$ gradient. Advances in Ecological Research, 42, 265-299.

Likens, G. E. \& Bormann, F. H. (1974) Linkages between terrestrial and aquatic ecosystems. Bio. Science, 24, 477-456.
March, J. G. \& Pringle, C. M. (2003) Food web structure and basal resource utilization along a tropical island stream continum, Puerto Rico. Biotropica, 35, 84-93.

McHugh, P. A., McIntosh, R. A. and Jellyman, P. G. (2010) Dual influence of ecosystem size and disturbance on food chain length in streams. Ecology Letters, 13, 881-890.

McLachlan, A. J. \& Ladle., R. J. (2009) The evolutionary ecology of detritus feeding in the larvae of freshwater Diptera. Biological Reviews, 85, 133-141.

Okun, N., Brasil, J., Attayde, J. L. \& Costa, I. A. S. (2008) Omnivory does not prevent trophic cascades in pelagic food webs. Freshwater Biology, 53, 129-138.

Olesen, J. M., Dupont, Y. L., O'Gorman, E., Ings, T. C., Layer, K. \& Melin, C. J. (2010) From Broadstone to Zackenberg: space, time and hierarchies in ecological networks. Advances in Ecological Research, 42, 1-69.

Parker, S. M. \& Huryn, A. D. (2006) Food web structure and function in two Arctic streams with contrasting disturbance regimes. Freshwater Biology, 51, 1249-1263.

Phillips, D. L. (2001) Mixing models in analyses of diet using multiple stable isotopes: a critique. Oecologia, 127, 166-170.

Polis, G. A., Anderson, W. B. \& Holt, R. D. (1997) Towards an integration of landscape and food web ecology: the dynamics of spatially subsidized food webs. Annual Review of Ecology and Systematics, 28, 289-316.

Rawcliffe, R., Sayer, C. D., Woodward, G., Grey, J., Davidson, T. A. \& Jones, J. I. (2010) Back to the future: using palaeo-limnology to infer long-term changes in shallow lake food webs. Freshwater Biology, 55, 600-613.

Rosi-Marshall, E. J. \& Wallace, J. B. (2002) Invertebrate food webs along a stream resource gradient. Freshwater Biology, 57, 129-141.

Rounick, J. S., Winterbourn, M. J. \& Lyon, G. L. (1982) Differential utilization of allochthonous and authocthonous inputs by aquatic invertebrates in some New Zealand streams: a stable carbon isotope study. Oikos, 39, 191-198.

Salas, M. \& Dudgeon, D. (2001) Laboratory and field studies of mayfly growth in tropical Asia. Archiv für Hydrobiologie, 157, 75-90.

Tavares-Cromar, A. F. \& Williams, D. D. (1996) The importance of temporal resolution in food web analysis: evidence from detritus-based streams. Ecological Monographs, 66, 91-113.

Thompson, R. M. \& Townsend, C. R. ((2004)) Energy availability, spatial heterogeneity and ecosystem size predict food-web structure in streams. Oikos, 108, 137-148.

Thomson, R. M., Dune, J. \& Woodward, G. (2012) Freshwater food webs: towards a more fundamental understanding of biodiversity and community dynamics. Freshwater Biology, 57, 329341.

Thomson, R. M. \& Townsend, C. R. (1999) The effect of seasonal variation on the community structure 
and food-webs atributes of two streams: implications for food-web science. Oikos, 87, 77422.

Townsend, C. R., Thomson, R. M., Mclntosh, A. R., Kilroy, C., Edwards, E. \& Scarsbrook, M. R. (1998) Disturbance, resource supply, and food-web architechture in streams. Ecology Letters, 1, 200209.

Vannote, R. L., Minshall, G. W., Cummins, K. W., Sedell, J. R. \& Cushing, C. E. (1980) The river continum concept. Canadian Journal of Fisheries and Aquatic Sciences., 37, 130-137.

Wallace, J. B., Eggert, S. L., Meyer, J. L. \& Webster, J. R. (1997) Multiple trophic levels of a forest stream linked to terrestrial litter inputs. Science, 5332 , 102-104.

Warren, P. H. (1989) Spatial and temporal variation in the structure of a fresh-water food web. Oikos, 55, 299-311.

Weidman, R. P., Schindler, D. W. \& Vinebrook, R. D. (2011) Pelagic food web interactions among benthic invertebrates and trout in mountain lakes. Freshwater Biology, 56, 1081-1094.

Winemiller, K. O. \& Polis, G. A. (1996) Food webs: what can they tell us about the world? Pages 1-22 in G.A. Polis and K.O. Winemiller (editors) Food webs: integration of patterns and dynamics. Chapman \& Hall, New York.

Winemiller, K. O., Zeug, S. C., Robertson, C. R., Winemiller, B. K. \& Honeycutt, R. L. (2011) Foodweb structure of coastal streams in Costa Rica revealed by dietary and stable isotope analyses. Journal of Tropical Ecology, 27, 463-476.

Woodwards., G., Ebenman, B., Ernmerson, M. \& Montoya, J. M. (2005b) Body size in ecological networks. Trends in Ecology and Evolution, 20, 402-409.

Yule, C. M. (1996) Trophic relationships and food webs of the benthic invertebrate fauna of two seasonal tropical streams on Bougainville Island, Papua New Guinea. Journal of Tropical Ecology, $12,517-534$ 